\title{
DEVELOPMENT STRATEGIES AND INTEGRATION WITH QUALITY OF TRANSPORT SERVICES
}

\author{
Professor Radica Pavlovic, PhD \\ Faculty for Business Studies, Pozarevac, Serbia, \\ rpavlovic@megatrend.edu.rs \\ Professor Slobodan Stamenkovic, PhD \\ Faculty for Business Studies, Pozarevac, Serbia, \\ sstamenkovic@megatrend.edu.rs \\ Professor Slobodan Stefanovic, PhD \\ Graduate School of Applied Professional Studies, Vranje, Serbia, \\ slobodanstef@gmail.com \\ Professor Radoje Cvejic, PhD \\ Faculty for strategic and operational management, Belgrade, Serbia \\ radoje.cvejic@fsom.edu.rs
}

\begin{abstract}
The shifting economy and changes in the company should be directed, within the concept of integration Republic of Serbia into the European Union, by implementation of a model of development of competitive abilities as forces of revival, growth and development. Based of the model of transformation of transport companies should implement monitoring and improving key business performances based on quality management.

Key words: Quality system, standardization, TQM
\end{abstract}

\section{INTRODUCTION}

Complexity of managing with strategic changes is evident in the global economic crisis periods, such as the present one. The process of change in complex systems, and each individual organization, implementation of strategy, is conditioned by a large number of decisions to be made in order to improve implementation, vision and strategy, and reduce resistance to change. The process of managing with strategic changesas itself is easier if in the strategic vision are given argumented facts of the transition from the current position in the futureand if the gap analysis show the difference that exists between the current position of the transport system of the Republic of Serbia and the developed countries of the transport system in Europe, especially the European Union, as a traget strategic position. This particularly, the association with and eventual entrance to the EU conditioned by the level of development of transport in the country so as providing conditions for unimpeded transit traffic.

\section{CRITERIA RELATED TO THE QUALITY OF BUSINESS RESULTS}

In the group of criteria related to the results, the most important are those related to the quality of products or services, as well as a set of criteria related to the company's business results, which include not only accomplish their goals, and a comparison with the results of the competition and the best organizations in the industry. It is understood that all criteria and subcriteria can and should be regularly monitored and quantified in order to define them on the basis of prevention and correction action. Business excellence models have an unusual opportunity for the company to improve its management, fully complementary to other methods and tools that provide quality products, services or processes.

Standardization of traffic is a very complex activity in the preparation, adoption and application of technical regulations and standards in this area. „It is, at first place, appeared as a result of the general requirements for the safe and efficient transfer and transport of people and goods, and then as an industry need for unification, standardization and interchangeability of components and component parts." $\left({ }^{1}\right)$ Vehicles are the main object of international transport, $\left({ }^{2}\right)$ and therefore one of the main subjects of international standardization.

(1) Labović, V., Savezni zavod za standardizaciju, Beograd, 
«Standardizacija u saobraćaju u funkciji poboljšanja usluga i smanjenja troškova», II kongres o saobraćaju, Dugoročni razvoj saobraćaja Jugoslavije 1999.god., str. 319.

(') Labović, V., Kvalitet, 40, broj 9-10, 1995.

Among the first cases in the international standardization appeared ships, aircraft and land vehicles and their respective technical committees of the International Organization for Standardization (ISO): ISO/TC 8 - Shipbuilding, ISO/TC 20 - Aircraft, ISO/TC 22 - Road vehicles, and later ISO/TC 188 - Small craft, while standardization in the field of railway vehicles developed in the framework of the International Union of Railways (UIC).

In addition to the International Organization for Standardization technical regulations and standards at the international, regional and sectoral levels for vehicles, among others, made the European Economic Commission of the United Nations - Committee on the Internal Transport (UN - ECE), the International Maritime Organization (IMO), the International Civil Aviation Organization (ICAO), the European association of aeronautical equipment (by road) and the European Union (EU) directives as the Council and the European standards. Technical regulations and standards of these organizations are commonly used as a basis for national technical regulations and standards in the field of transport.

Founds of internal transport are part of the transport system related to the storage and transport terminals, and their standardization has priority impact on the safety and protection of the environment, on the one hand, and the rationalization of storage and transshipment operations, on the other hand. The application of standards in this area bring following ISO technical committees: ISO/TC 96 - Cranes, ISO/TC 101 - Equipment for continuous transfer of cargo, ISO/TC 110 - internal transport vehicles and ISO/TC 178 - Lifts. Their equivalent technical committees of the European Organization for standardization are - CEN/TC 147, CEN/TC 148, CEN/TC 150 and CEN/TC 10. European standards in this field almost exclusively handle the security aspect. The European Union has issued directives five devices for lifting (lift) and one a self-propelled vehicle directive for internal transport.
Transportation infrastructure, in these considerations limit to traffic signaling and equipment of public roads. It is largely the subject of national standardization of individual countries, and the last decade, the Technical Committee CEN/TC 226 - Travel Gear. Scope of work as horizontal and vertical signage, temporary signage, traffic control equipment and the equipment of public roads.

Performance of services, such as product performance, are increasingly becoming the subject of standardization in some areas. In the area of transport, standardization of quality of service and its performance, occurs primarily in the transportation of passengers to and from the two characteristic features: in systems where transport companies free to organize its services and in systems where transport companies must comply with the technical specification of the body. In both cases, in the role like ,client“ appear: A)the passenger, immediate customer service; B)authority which establish technical specifications; C)an entity that provides/organize a trip; and G)citizen in the broadest sense, as a potential customer. Categories of quality criteria in this standard is the services provided to passengers and that can be controlled by the company.

Quality criteria which can be applied to all transport modes according to the literature, $\left(^{3}\right)$ are shown in the following Table 1.

The concept of performance standards for transport services is to enable the determination of appropriate quality indicators for different types of traffic, there by enabling comparisons of services. Further adjustment goes against certain types of traffic to be defined: the categories of quality criteria; appropriate indicators and their way of working out and calculating and the level of quality which is achieved by using these indicators, Table 2. 
$\left({ }^{3}\right)$ AFNOR, Francuski standard XP X 50-805, 1997. god.

Table 1. Categories of quality criteria

\begin{tabular}{|c|c|c|}
\hline Criterion & Anexis & Comments \\
\hline Informing & $\mathrm{A}$ & \\
\hline Escort & $\mathrm{B}$ & \\
\hline Regularity/Accuracy & $\mathrm{C}$ & \\
\hline Availability of equipment & $\mathrm{D}$ & $\begin{array}{l}\text {-Equipment is closely related to travel (train tickets } \\
\text { distributors, toll gates, elevators, moving sidewalks, ...); } \\
\text {-Equipment related services (telephone, beverages and candy } \\
\text { distributor, distributors, notes, ...). }\end{array}$ \\
\hline $\begin{array}{l}\text { Cleanliness / tidiness } \\
\text { - Clean the infrastructure } \\
\text { (rail and bus stations, } \\
\text { subway, ...) } \\
\text { - - Clean transport module }\end{array}$ & $\mathrm{F}$ & \\
\hline Comfort/load rate & $G$ & \\
\hline Security & & $\begin{array}{l}\text { This is extremely important criterion appears in many forms. } \\
\text { The aspect of "Safety function", which also includes the } \\
\text { security of the system, is a decisive factor in quality. } \\
\text { "Feelings of insecurity" are subsumed under the criterion of } \\
\text { "cleanliness/tidiness," in which the company may be affected. } \\
\text { Other aspects (the presence of the police force, for example.) } \\
\text { Are the responsibility of other agencies and the company's } \\
\text { indispensable partner. }\end{array}$ \\
\hline $\begin{array}{l}\text { Avoiding to pay for } \\
\text { the ticket }\end{array}$ & & $\begin{array}{l}\text { Failure to pay a ticket can take many forms. In the case of road } \\
\text { transport system, and in particular the city, regardless of the } \\
\text { system dohodovanja companies, risk or guarantee of income, } \\
\text { failure to pay a ticket that affects the quality of their } \\
\text { financial performance, and behavior that causes it. Just this last } \\
\text { aspect is treated in the criterion of "comfort." }\end{array}$ \\
\hline
\end{tabular}

Source: Vaso Labovic, dipl.ing., Federal Bureau of Standards, op.cit. 1

TABLE 2. INDICATORS AND THEIR WAY OF ELABORATION

\begin{tabular}{|c|c|}
\hline CRITERION & Sub-criteria \\
\hline \multirow{6}{*}{ Favors action and its follow-up } & - In correlation with the levers of action \\
\hline & - Reliable \\
\hline & - Sensitive \\
\hline & $\begin{array}{l}\text { - Not improved (can not be improved without } \\
\text { improve the service, for example.: - Lost kilometers) }\end{array}$ \\
\hline & - The system of measurement that is not a sanction \\
\hline & - Zastarelost measurements in time \\
\hline \multirow{4}{*}{ Communicative } & - Understandable for all \\
\hline & - Customizable \\
\hline & - Acknowledged \\
\hline & - Local customizable \\
\hline \multirow{3}{*}{ Easy to measure } & - Simple \\
\hline & - Inexpensive to measure \\
\hline & - It can be objectively quantified, even if the qualitative \\
\hline \multirow[b]{2}{*}{$\begin{array}{l}\text { Focused on client } \\
\text { (customer) }\end{array}$} & - perceived by the client (customer) \\
\hline & $\begin{array}{l}\text { - It can be expressed by number of served (or not served) customers } \\
\text { (buyers) }\end{array}$ \\
\hline
\end{tabular}


Quality indicators are selected to suit the service and that are coherent with the types of traffic and businesses. According to the literature recommendations for defining indicators are given in the table. Determining the quality of service in this way it is possible by first defining the threshold of unacceptability to the highest level. The application of the criteria for quality of service based on possible indicators contained in the standards of France is not possible in other modes of transport, but a good basis for the development of national standards, amended with other regulations. The quality system is developed and implemented in order to achieve the goals set in the quality policy of the organization.

The quality control system, according to the model chosen one of the standards JUS ISO 9001, JUS ISO 9002, and JUS ISO 9003, as basic goal sets customer satisfaction by preventing nonconformity at a certain stage of its delivery - from design to maintenance. Services in the field of transport is the main means of trade and as such must have agreed operational procedures, equipment and organization, more than in any other field. World Trade Organization Agreement on rules for the free and fair exchange of goods and services at the global level, in order to realize its full potential, is supported by technical agreements, in order to obtain compatibility of technologies in the field of transport around the world. Categorization of quality criteria and selection of indicators of transport services contribute to the quantification of the quality of service, compared to the costs incurred in providing the services, it becomes comparable to the same and different modes of transport, and different levels of performance. Failure to comply or failure to apply the principles of standardization, at any level in the chain of service, reflects negatively on the service itself with consequences that may be within the limits of a simple increase in the cost to the impossibility of providing such services.

Quality of transport services in the global transport system and in various traffic subsystems or divisions, for example, by means of transport, spatial and time zones, the categories of passengers and goods, and so on can be viewed, analyzed and defined in various ways. As general characteristics of service quality in Table 3. stand out: $\left(^{4}\right)$

1. Quality-Complexity refers to the number of different elements or features that make up the quality of transport services, and can be displayed by parameters given in the table,

2. The possibility of merging - integration of parameters that make up the service and who have individual characteristics,

3. Bipolarity - which means that each characteristic of the service can be expressed with two opposite characters on evaluation list,

4. The possibility of measuring on the quality scale - and is related to the evaluation respectively measurement for each particular trait or element and that from zero or minimum to optimum. For quantitative measurement (evaluation) must be set method of translating qualitative elements of transport service in numerical values of the elements of transport service,

5. The possibility of evaluating the similarity of services - qualitative elements of the transportation services may have similarities.

On the other hand, the quality of transport services can be viewed in two ways, from the viewpoint of a service provider offering quality, transportation and customer service - the required quality. A comparative overview of the elements related to transportation services and for water transport, rail and road transport, $\left({ }^{5}\right)$ are given in the Table 4.

$\left({ }^{4}\right)$ Радмиловић, 3., Зобеница, Р., Саобраћајни факултет Универзитета у Београду, Београд, "Квалитет превозне услуге у речном саобраћају с посебним прилогом истраживања квалитета транспортних средстава", II конгрес о саобраћају, ДУГОРОЧНИ РАЗВОЈ САОБРАЋАЈА СРЈ,1999., стр.335 $\left(^{5}\right)$ UNCTAD experts, Multimodal Transport and Containerization, UN, TD/B/C.4/238/Rev.1., New York, 1984., стр. 336 
Table 3. General performaces service quality

\begin{tabular}{llll}
\hline Elements related to: & & & \\
\hline SPACE & TIME & SPENT WORKING & TRANSPORTED SUBJECT \\
\hline $\begin{array}{l}\text { Accessibility of transport } \\
\text { Network }\end{array}$ & Speed & Transport cost & Masssive scale \\
\hline $\begin{array}{l}\text { Direct } \\
\text { transport }\end{array}$ & $\begin{array}{l}\text { Accessibility } \\
\text { by time }\end{array}$ & Capital investment & Security \\
\hline Travel distance & Frequency & Comfort of travel \\
\hline Throughput capacity & Reliability & \\
\hline & Rhythmicity & \\
\hline & Regularity & \\
\hline & Accuracy & \\
\hline
\end{tabular}

Source: UNCTAD experts, Multimodal Transport and Containerization, UN, TD/B/C.4/238/Rev.1., New York, 1984

Table 4. Comperative traffic from the point of view of quality transportation

\begin{tabular}{|c|c|c|c|c|}
\hline \multirow[t]{2}{*}{$\begin{array}{l}\text { Elements of } \\
\text { service quality }\end{array}$} & \multirow[t]{2}{*}{$\begin{array}{l}\text { River } \\
\text { traffic }\end{array}$} & \multicolumn{2}{|c|}{ Train service } & \multirow[t]{2}{*}{$\begin{array}{l}\text { Road } \\
\text { traffic }\end{array}$} \\
\hline & & $\begin{array}{c}\text { Conventional } \\
\text { trains }\end{array}$ & $\begin{array}{l}\text { Train with } \\
\text { marshute }\end{array}$ & \\
\hline $\begin{array}{l}\text { Transit time } \\
\text { (speed) }\end{array}$ & + & - & + & ++ \\
\hline The ability to transport & & & & \\
\hline " door to door" & -- & - & -- & ++ \\
\hline Reliable transport & + & + & ++ & + \\
\hline Security Service & + & + & ++ & ++ \\
\hline Security Service & ++ & ++ & ++ & + \\
\hline Adaptability transport & + & - & + & ++ \\
\hline Persistence transport & + & + & + & ++ \\
\hline Energy capacity & ++ & + & + & -- \\
\hline Ecological impact & ++ & - & - & -- \\
\hline
\end{tabular}

L e g e $\mathrm{n}$ d : ++ + very high quality transportation services,

$+\bullet$ high quality transportation services,

- low quality of transport services, and

- a very low quality of transport services

Source: UNCTAD experts, Multimodal Transport and Containerization, UN, TD/B/C.4/238/Rev.1., New York, 1984. 


\section{TQM APPROACH TO CONTINUOUS IMPROVEMENT OF QUALITY}

A particularly important goal of the strategic management of traffic and transport system of the Republic of Serbia is certainly a quality management services, quality systems and processes that are used to create and maintain high quality required by consumers or service users. „Quality management process is connected with the management of internal operations and marketing. It requires a clear understanding of consumer desires and capabilities of the organization to meet them". $\left({ }^{6}\right)$ Systems improvement and quality management have developed rapidly since the level of quality inspection,

$\left.{ }^{6}\right)$ Ljubojević, Č., "Marketing usluga", Presing, Beograd, 1996., str 83.

quality control, quality assurance, total quality con control, to TQM (Total Quality Management) approach to quality.

A key element of the TQM approach to continuous quality improvement, concentrating on how to become a top notch organization in the results. The process of improving the quality of service in transport is not an easy process, and it is necessary to predict the important steps that can lead to success, including:

- Identify the primary determinants of service quality,

- managing the expectations of consumers,

- manage forms,

- consumer education related to the service,

- developing a quality culture,

- automaticity quality, and

- monitoring services.

\section{CONCLUSION}

The realization of the process of improving the service quality, in all its stages, requires constant management to return preliminary information gathering and revaluation of business processes. The complexity of continuous quality improvement is conditioned the need for continuous learning in order to develop the ability to react to changing consumer demands and specifications. Benchmarking represent an accelerated learning organization (acquisition of knowledge, skills and abilities) and improve their performance as ,continuous process of measuring products, services and practices towards the strongest competitors or those companies recognized as industry leaders", ${ }^{7}$ )respectively it is the search for best practices in those organizations that lead to superior performance. Learning from ,the best" organizations can shorten the cycle time for the improvement of their own services. In the framework of defining the objectives, one of the most important places has a future system of statisticinformation technology and that to the program of interests for entire country, the use of existing statistical-information (SI) system and the further development of the SI system traffic.

Well-defined communication strategy allows to effectively manage the overall communications as ,element indirect support to achieving strategic goals of structural reform in the Yugoslav traffic. Quality, speed and dinamic of structural reform will depend not only on the quality and feasibility conceived vision, but also the degree of (non) existence of adequate support from key target groups of internal and external public", $\left({ }^{8}\right)$ rounding uniqueness and importance of this goal. Considering the framework necessary standardization of the basic parameters of navigation on the inland waterway network, particularly significant step is the formation of an information system and 
the use of geographic information system GIS. This information system provides spatial data management, graphic and alpha-numeric data relevant to the fairway and the infrastructure that supports the inland transport and its relationship to other forms of transport. $\left({ }^{9}\right)$

\section{LITERATURE}

1. AFNOR, Француски стандард XP X 50-805, 1997. год.

2. UNCTAD experts, Multimodal Transport and Containerization, UN, TD/B/C.4/238/Rev.1., New York, 1984

3. Војводић, Р.,"Комуникациона стратегија-елемент непосредне подршке остваривања циљева структурних реформи у саобраћају", Врњачка Бања, 1997.

4. Мушкатировић, J., Саобраћајни Факултет, Универзитета у Београду, "Могућности развоја унутрашњег водног саобраћаја применом GIS - a“, II конгрес о саобраћају, Дугорочни развој саобраћаја Југославије 1999.

5. Matejić, V., Novi proizvodni sistem na globalnom nivou i kultura na jugoslovenskom prostoru: ishodi najverovatnijih interakcija, Beograd, 1994. god.

6. Hofer, C i dr., Strategy formulation, Andytical Concepts-St. Paul West Publishing, 1978,

7. Ljubojević, Č., "Marketing usluga", Presing, Beograd, 1996.

8. Arnoldo, H. i drugi, Strategic Management: An Integrative Perspektive, Prentice-Hall, 1984.

9. OECD (1992b), Technology and Economy, The Key Relationships, Paris.

10. Labović, V., Savezni zavod za standardizaciju, Beograd, «Standardizacija u saobraćaju u funkciji poboljšanja usluga $i$ smanjenja troškova», II kongres o saobraćaju, Dugoročni razvoj saobraćaja Jugoslavije 1999.god.

11. Labović, V., Kvalitet, 40, broj 9-10, 1995.

12. Radmilović, Z., Zobenica, R., Saobraćajni fakultet Univerziteta u Beogradu , Beograd, "Kvalitet prevozne usluge u rečnom saobraćaju s posebnim prilogom istraživanja kvaliteta transportnih sredstava", II kongres o saobraćaju, Dugoročni razvoj saobraćaja SRJ,1999.
13. Stamenković, S., (2008) Corporate Social Responsibility, Denbridgr Press, New York.

14. Stamenković, S., Pavlović, R., «Upravljanje vodnim resursima $u$ saobraćajnom sistemu $R$. Srbije», Prvi simpozijum o upravljanju prirodnim resursima sa međunarodnim učešćem, Zbornik radova, Bor, maj 2011. 